\title{
Modification of gene expression induced by siRNA targeting of estrogen receptor $\alpha$ in MCF7 human breast cancer cells
}

\author{
Y.A. LUQMANI ${ }^{1}$, A.AL AZMI ${ }^{3}$, M.AL BADER ${ }^{2}$, G. ABRAHAM ${ }^{1}$ and M. EL ZAWAHRI ${ }^{3}$ \\ Faculties of ${ }^{1}$ Pharmacy and ${ }^{2}$ Medicine, Kuwait University, Safat 13110; \\ ${ }^{3}$ Faculty of Science, Kuwait University, Safat 13060, Kuwait
}

Received June 18,2008; Accepted August 25, 2008

DOI: 10.3892/ijo_00000145

\begin{abstract}
To establish a model of endocrine resistant breast cancer that is associated with loss of estrogen receptor (ER), MCF7 cells were transfected with several plasmid constructs intended to produce intracellular double stranded hairpin RNA to be processed into siRNA directed against different regions of the ER $\alpha$ mRNA. Stably transformed cells were propagated in long-term culture. One of these lines, designated pII, was selected for further analysis. pII cells exhibited reduced levels of ER $\alpha$ mRNA and protein as well as several estrogen-regulated genes assessed by real-time PCR and were unresponsive to addition of estradiol and tamoxifen. Higher levels of ERß were measurable as compared with parental MCF7 cells. There was an unexpected decrease in expression in members of the EGFR family in contrast with observations reported for ER-negative tumours or some other established endocrine-independent lines. Microarray gene analysis comparing expression in parental MCF7 with pII cells in both serum-synchronised and non-synchronised conditions highlighted a spectrum of other genes that were expressed at different levels compared to the parental MCF7 cells. Genes showing the greatest change were mostly common between synchronized and unsynchronised cells; GRB7, PSMD7, KRT19, KRT18, AKT1, SYNCRIP, CYB5A and EVL for down-regulated in pII and QDPR, VIM, CD68, CA9, STMN1, CDK2, CTSC for up-regulated in pII cells. Notably, the decreased expression of epithelial keratins 18 and 19 and an increase in vimentin and in a macrophage marker CD68, is suggestive of an epithelial to mesothelial transition. Further characterisation of these cells particularly with respect to the factors controlling their growth may contribute to a better understanding of the behaviour of
\end{abstract}

Correspondence to: Dr Y.A. Luqmani, Faculty of Pharmacy, Kuwait University, P.O. Box 24923, Safat 13110, Kuwait

E-mail: yunus@hsc.edu.kw

yluqmani@yahoo.com

Key words: siRNA, estrogen receptor, breast cancer, endocrine resistance, microarrays, PCR cells that have become endocrine independent by loss of ER function.

\section{Introduction}

The role of estrogen mediated through the estrogen receptor (ER) (1) has been long established in the pathogenesis of human breast cancer, a disease that is the second leading cause of cancer mortality among women worldwide. In addition to surgical ablation, radiotherapy and chemotherapy, endocrine agents have played a pivotal role in the management and treatment of this neoplasm. For the $60-70 \%$ of women with a clinically defined positive tumour ER status, the application of anti-endocrine agents has resulted in significant benefit both in terms of quality of life and overall length of survival (2). Blockade of metastatic tumour growth in such patients is achieved by either of three means; i) physiological downregulation of ovarian estrogen secretion by surgical ablation and/or antagonism of the pituitary hormones controlling steroid hormone production, primarily with LHRH analogues such as goserelin; ii) reduction of peripherally produced non-ovarian estrogen primarily from the adrenals or adipose tissue including that of the breast itself with aromatase inhibitors such as anastrazole (3), principally for postmenopausal women; and iii) direct apposition of estrogen action with pharmacological receptor antagonists referred to as selective estrogen receptor modulators (SERMS). The most effective and widely prescribed of the latter group, tamoxifen $(4,5)$, has been the mainstay of endocrine therapy for the best part of three decades. However, despite the fact that tamoxifen is considered the standard care for treatment of $\mathrm{ER}^{+}$breast cancer (3), it has certain drawbacks such as increased occurrence of vaginal discharge, hot flushes, blood clots and most seriously increased risk of endometrial cancer (6), although this is not substantial. Additional complications addressed further below are due to partial agonist activity thought to be mediated through the transactivation function 1 (AF1) of the ER $(7,8)$. This has led to extensive efforts to develop alternative SERMS which either lack the agonist properties and/or have reduced undesired effects (9). Prominent among these are raloxifene (10), the $11 ß$ substituted derivatives like RU58668 (11) or the pure anti-estrogen fulvestrant (referred to as a SERD; selective estrogen receptor down-regulator) which impairs receptor dimerisation, blocks nuclear localization and leads to accelerated ubiquitylation and proteasomic degradation of 
the ER (12). Many of these compounds as well as a variety of aromatase inhibitors have had success in clinical trials.

Unfortunately, none have been able to effectively overcome the phenomenon termed 'endocrine resistance'. Half of advanced breast cancer patients (and a $\sim 30 \%$ of $\mathrm{ER}^{+}$ ones) are de novo un-responsive to first line tamoxifen, and practically all of those with metastatic disease and as many as $40 \%$ of those receiving adjuvant tamoxifen, experience relapse and rapid decline. Brief respite can sometimes be achieved by switching between different classes of drugs that either antagonise ER or reduce estrogen levels. Subsequent shift to chemotherapy is largely unsuccessful and frequently debilitating.

The combination of de novo and acquired resistance presents a major challenge to an otherwise promising strategy to deal with a disease that is predicted to afflict some five million women in the next decade (13). A number of explanations have been proposed to account for the progressive loss of response to tamoxifen and endocrine therapy in general (14-18).

These may be classified into the following broad categories: i) alteration or loss of function of the ER or loss of expression; ii) sub-cellular re-distribution of the receptor between nucleus and cytoplasm; iii) alteration in expression or function of co-regulators; iv) increased metabolism of endocrine agent; v) increased growth factor signaling; vi) so far undefined actions of ERß. Each of these possible effects has been investigated using varying types of in vitro cellular model systems, generally following two patterns; adaptation of cells to estrogen withdrawal as with the LTED cells developed by Santen's group (19) and survival in the presence of sub-toxic levels of tamoxifen (20-22) to induce the development of a resistant phenotype. There is evidence to support each of the above hypotheses but individually none can account for a sufficiently meaningful proportion of occurrences of resistance. Lack of receptor is certainly the case for de novo resistance. Acquired receptor loss appears to be associated with a minority (17-28\%) of patients displaying tamoxifen resistance (23); at least $20 \%$ of such resistant patients respond to second line therapy with aromatase inhibitors suggesting the continuing functional capacity of the ER. Restoration of tamoxifen sensitivity was achieved in the ER-negative MDAMB231 cells with demethylating agents (24) although ectopic expression of ER failed to achieve this (25). ER positivity alone could be modulated in ZR-75 derived 9a1 cells by addition and removal of tamoxifen (26). Several contrasting models of fulvestrant resistant cells have been reported that show: i) complete ER protein loss (27); ii) $90 \%$ decrease in ER mRNA and protein accompanied by functional changes in ER target genes (28); iii) 30\% reduction of ER and maintenance of its function (29); and iv) additional cross-resistance to tamoxifen but with elevated levels of ER compared to the sensitive parent line (30).

The action-reaction hypothesis illustrated by Normanno and colleagues (17), summarises the events that might occur in the transition from an endocrine responsive to an estrogen independent phenotype based on observations using the various reported cellular models. From the diversity of observations ranging from loss of sensitivity to estrogen to hypersensitivity it seems reasonable to conclude that cellular response in these model systems is dependent upon the manner in which endocrine resistance is simulated.

With the increasing body of data indicating a so-called 'non-genomic' action of ER through a cytoplasmic or cell membrane associated receptor (31), possibly in the form of a splice variant (32), attention has also focused on the involvement of other growth stimulatory pathways. It has long been known that breast tumours exhibit an inverse relationship between ER and EGFR expression and inevitably this has led to a number of studies to investigate the interaction of the EGFR/HER2 and insulin-like growth factor (IGF) group of receptors, and ER activated pathways. There are suggestions of a bidirectional crosstalk involved in the activation of downstream signaling cascades through intermediates that include p42/44 mitogen activated protein kinase (MAPK) and AKT which orchestrate proliferation and cell survival via ras and PI3K (33-35). Over-expression of HER2 is associated with endocrine resistance in advanced breast cancer patients (36). Indeed, both tamoxifen as well as fulvestrant treated MCF7 cells display increased EGFR dependence as they acquire resistance $(21,37)$. In both cases, inhibition of the EGFR signaling overcomes the resistance.

In this study our aim was to determine global phenotypic changes arising from a very specific disturbance of ER function in breast cancer cells. To do this we established a cell model with a down-regulated ER achieved by a strategy that avoids the long-term exposure to endocrine agents employed in previous studies, by utilising the RNA interference pathway (38). To do this we targeted the receptor in MCF7 cells with an antisense sequence generated from a vector-based construct producing intracellular short hairpin (sh) RNA to mediate mRNA degradation through formation of the 'RNA-induced silencing complex'. We have established long-term cultures of selected transformants and present data showing comparative patterns of gene expression in these cells as compared with the parental cell line.

\section{Materials and methods}

Cell lines. MCF7 human breast carcinoma cells originating from the ATCC (American Type Culture Collection, Manassas, VA, USA) were kindly provided by Dr C. Ford (Kuwait University). Cells were routinely maintained at $37^{\circ} \mathrm{C}$ in a humidified atmosphere of $5 \% \mathrm{CO}_{2}$ in DMEM (Invitrogen, USA) supplemented with $10 \%$ fetal bovine serum (FBS) (Gibco, NY, USA), $600 \mu \mathrm{g} / \mathrm{ml}$ of L-glutamine, $100 \mathrm{U} / \mathrm{ml}$ penicillin, $100 \mu \mathrm{g} / \mathrm{ml}$ streptomycin and $6 \mathrm{ml}$ non-essential amino acids.

Design and construction of ER siRNA plasmids. Three different ER constructs were designed from the M12674 GenBank sequence of human ER $\alpha$ using the GenScript siRNA online designer programme for selection. These are shown in Fig. 1. The sense and corresponding inverted antisense ER sequences were joined by a 9 nucleotide intervening sequence designed to create a hairpin structure upon intracellular transcription which would be processed into short inhibitory RNA (siRNA). These three sequences were cloned into the $B a m \mathrm{H} 1$ and HindIII sites in the polylinker region of the $p$ RNA-U6.1/Neo siRNA expression vector (GenScript, NJ, USA) downstream of 


\section{pI GGATCCCGIATGGCTATGgAATCTGCITCAAGAGAGCAGATTCCATAGCCATACITITITCCAAAAGCIT

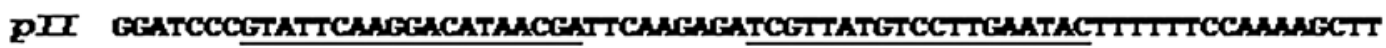

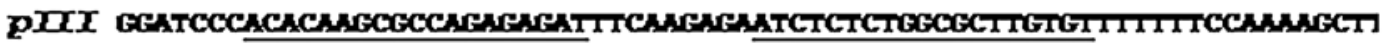

\begin{tabular}{clccc|c} 
|BamH1| & Sense & I Loop & antisense & [Termination|HindI] \\
gite & ER seq & & ER seq & Signal site
\end{tabular}

Figure 1. The constructs shown above were cloned into the BamH1/HindIII sites of pRNA-U6.1/Neo Genscript vector in frame with the U6 promoter. The sense and antisense sequences (underlined) were designed to form a hairpin RNA duplex upon intracellular transcription of this region.

a U6 mammalian promoter. The plasmid was transfected into DH5 $\alpha$ competent cells (Invitrogen, USA) and re-isolated from medium scale cultures using Qiagen plasmid purification kits. Insert sequences were verified by dideoxy DNA sequencing. As a control, we also transfected cells with the vector without any siRNA sequence. All plasmids were linearised by digestion with $B g l I I$ followed by re-precipitation and re-constitution into $10 \mathrm{mM}$ Tris $\mathrm{HCl}, 1 \mathrm{mM}$ EDTA pH 7.4.

Transfection of plasmid vectors. MCF7 cells were seeded in antibiotic-free medium into 6-well plates and allowed to attach. After $24 \mathrm{~h}$, each of the three ER plasmid constructs or control plasmid (either undigested or in linearised form), mixed with either X-tremeGENE reagent (Roche, Manheim, Germany) or Lipofectamine ${ }^{\mathrm{TM}} 2000$ transfection reagent (Invitrogen, Cambridge, UK) following the manufacturer's instructions, were added to the cells. Either 6 or 24 h later, the medium was changed and cells allowed to recover for a further $24 \mathrm{~h}$ before serial dilution into 12-well plates containing complete DMEM including selection antibiotic, G418 $(1.5 \mathrm{mg} / \mathrm{ml})$ (Sigma, USA). Medium was replaced every few days to remove dying cells and surviving cells were eventually transferred into fresh 6-well plates and individual cell clusters picked from outgrowths by scraping into a microtip. Single cell derived clones were serially expanded and passaged at least 15 times in G418 containing medium before using for analysis. For the control plasmid, we used only a single condition with $4 \mu \mathrm{g}$ linearised DNA with 24-h exposure using the X-tremeGENE reagent.

DNA extraction and PCR analysis of plasmid sequences. DNA was isolated from frozen $\left(-70^{\circ} \mathrm{C}\right)$ cell pellets using a PureGene kit (Gentra, Minneapolis, MN, USA) in accordance with the manufacturer's instructions. To verify the presence of the plasmid in the transfected clones, isolated DNA was subjected to amplification using four sets of primers that spanned different regions of the vector (5'-3' forward and reverse pair 1 , tacgatacaaggctgttagagag and tagaaggcacagtcg agg; pair 2, ggagaggctattcggctatg and gacaggtcggtcttgacaaa; pair 3, tctgcttagggttaggegtt and ttcatgettctcctccettt, pair 4: tctgcttagggttaggcgtt and tagaaggcacagtcgagg. A fifth pair (tacgatacaaggctgttagagag and atcgttatgtccttgaatacgg) was used for cells transfected with the pII construct to confirm the presence of the ER siRNA insert. As control, sequences for glyceraldehyde 5'-phosphate dehydrogenase (GAPDH) were also amplified using primers tcccatcaccatcttcca and catcacgccacagtttcc. A 50- $\mu 1$ standard reaction contained 100 pg DNA, 100 pmol of individual primer pairs (synthesised by Oswel, UK), $2 \mathrm{mM} \mathrm{MgCl}$ and $1.25 \mathrm{U}$ of AmpliTaq DNA polymerase (Perkin-Elmer, USA) which after an initial incubation at $95^{\circ} \mathrm{C}$ for 5 min was subjected to 40 cycles (in a Perkin-Elmer 9600 thermocycler) of denaturation at $95^{\circ} \mathrm{C}$ for $30 \mathrm{sec}$, annealing at $60^{\circ} \mathrm{C}$ for $30 \mathrm{sec}$ and extension at $72^{\circ} \mathrm{C}$ for $30 \mathrm{sec}$ (with final extension step of $10 \mathrm{~min}$ ). Products were electrophoresed on $1 \%$ agarose and visualised with ethidium bromide on a UVP UV gel documentation system.

Real-time PCR analysis. Total cellular RNA was extracted from frozen cell pellets using the RNAWIZ protocol (Ambion, Huntington, UK) and quantitated by spectrometry. Traces of DNA were removed by prior incubation with $1 \mathrm{U}$ of DNase and $40 \mathrm{U}$ of RNasin. First strand cDNA synthesis $\left(42^{\circ} \mathrm{C}\right.$ for $\left.50 \mathrm{~min}\right)$ was performed with $2 \mu \mathrm{g}$ RNA in $20 \mu \mathrm{l}$ buffer containing $25 \mathrm{mM}$ Tris- $\mathrm{HCl} \mathrm{pH} 8.3,37.5 \mathrm{mM} \mathrm{KCl}$, $1.5 \mathrm{mM} \mathrm{MgCl}_{2}, 5 \mathrm{mM}$ DTT, $500 \mu \mathrm{M}$ dNTP mix, $100 \mathrm{ng}$ random hexamers (Pharmacia Biotech, Uppsala) and $200 \mathrm{U}$ SuperScript II RNase $\mathrm{H}^{-}$reverse transcriptase (Gibco BRL). Heat-inactivated products were then subjected to PCR amplification initially performed using the Roche LightCycler instrument (for data shown in Figs. 3 and 6) using the LC DNA Master SYBR Green 1 kit. The cDNA $(1 \mu \mathrm{l})$ was added to the LightCycler mix containing $2.4 \mu \mathrm{l}$ of $25 \mathrm{mM} \mathrm{MgCl}_{2}, 2 \mu \mathrm{l}$ SYBR Green reaction mix, $1 \mu 1$ of primers $(20 \mu \mathrm{M})$ and water to a final volume of $20 \mu 1$ and then transferred into the capillary tubes of the LightCycler. Cycling parameters were as described in the manufacturer's protocol except that fluorescence acquisition mode was set at $82^{\circ} \mathrm{C}$ following each extension step, to avoid potential contribution from any non-specific products such as primer dimers. Primer sequences used (5'-3') were: ER $\alpha$, ggagacatgagagctgccaac and ccagcagc atgtcgaagatc; Cathepsin D, gtgccetgccagtcagcgtcgtcag and cctgctcaggtagaaggagaagatg; pS2, aggcaatggccaccatggag and aaagtcagagcagtcaatct; PR, cccacaggagtttgtcaagctc and taacttcagacatcattccgc; erbB2, cacagacacgtttgagtcca and aaagctctccggcagaaatg; EGFR, ccaggaacgtactggtgaaa and taggcactttgcetcettct; actin, gtcetgtggcatccacgaaact and tacttgcgctcaggaggagcaa.

In a subsequent procedure (for the data shown in Fig. 5), quantitative PCR was also performed using the Applied Biosystems 7500 cycler. Reactions were prepared as above but using the SYBR Green master mix (no. 4309159) from Applied Biosystems, USA. Amplification was performed as per the manufacturer's protocol for this kit. Melting curve analysis was performed at the end of 60 cycles to confirm a single product. Primer sequences used in these analyses were (5'-3'): for ER $\alpha$, atggaatctgccaagaagact and gcgcttgtgtttcaaca 
ttct; for ERß1, cgatgctttggtttgggtgat and gecetttgcttttactgtc; for actin, gtcctgtggcatccacgaaact and tacttgcgctcaggaggagcaa.

The ratio of ER $\alpha$ and ERß1 to the normalising gene (actin) was calculated by the method of Pfaffl (39). Other methods, including the use of an external standard (cytokine RNA series) gave essentially similar results.

Protein analysis by Western blotting. Cell pellets from parent MCF7 and transfected pII and control lines, either fresh or frozen, were re-suspended (typically $5 \times 10^{6}$ cells $/ 135 \mu \mathrm{l}$ ) in ice-cold lysis buffer; $10 \mathrm{mM}$ Tris- $\mathrm{HCl} \mathrm{pH}$ 7.4, $1.5 \mathrm{mM}$ EDTA, $10 \% \mathrm{v} / \mathrm{v}$ glycerol, $1 \mathrm{mM}$ DTT, $1 \mu \mathrm{g} / \mathrm{ml}$ leupeptin, $100 \mu \mathrm{g} / \mathrm{ml}$ bacitracin, $2 \mu \mathrm{g} / \mathrm{ml}$ aprotinin and $1 \mu \mathrm{g} / \mathrm{ml}$ pepstatin. The mixture was vortexed briefly, sonicated for $30 \mathrm{~min}$ at $4^{\circ} \mathrm{C}$ followed by freezing for $15 \mathrm{~min}$ (steps repeated 3 times) and centrifuged at $21,000 \mathrm{~g}$ for $30 \mathrm{~min}$ at $4^{\circ} \mathrm{C}$. Cleared supernatants were collected and protein concentration determined using Coomassie Plus Protein assay reagent (Pierce \& Warner Ltd., UK). Samples were stored at $-70^{\circ} \mathrm{C}$ prior to analysis. Lysates containing about $20-30 \mu \mathrm{g}$ protein and molecular weight rainbow markers (14.300-220 kDa; Amersham Pharmacia Biotech, UK) were mixed with loading buffer (0.03\% w/v bromophenol-blue, $32 \mathrm{mM}$ Tris-HCl pH 6.8, 8\% w/v dithiothreitol and $4 \% \mathrm{w} / \mathrm{v}$ SDS), boiled for $5 \mathrm{~min}$, then chilled on ice and centrifuged (10,000 g for $1 \mathrm{~min})$. Samples were then electrophoresed (SDS-PAGE; $7.5 \%$ polyacrylamide gels) in $25 \mathrm{mM}$ Tris- $\mathrm{HCl} \mathrm{pH} 8.3,150 \mathrm{mM}$ glycine, $20 \% \mathrm{v} / \mathrm{v}$ methanol, $0.1 \% \mathrm{w} / \mathrm{v}$ SDS). Gels were equilibrated in transfer buffer and protein was transferred to PVDF membranes (Amersham Pharmacia Biotech, UK) by electroblotting with a constant current of $300 \mathrm{~mA}$ overnight with cooling. After transfer, membranes were dried and stored at $4^{\circ} \mathrm{C}$.

For immunodetection, membranes were blocked for $1 \mathrm{~h}$ at room temperature with $10 \%$ non-fat dry milk in TBS-T (20 mM Tris, $137 \mathrm{mM} \mathrm{NaCl}, \mathrm{pH} 7.6$ and $0.1 \% \mathrm{v} / \mathrm{v}$ Tween), thoroughly washed by repeated rinses in TBS-T and then incubated overnight at $4^{\circ} \mathrm{C}$ with $\mathrm{ER} \alpha-\mathrm{S}$ monoclonal antibody (\#C-311; Santa Cruz Biotechnology, Inc., USA) diluted 1:500 in $5 \% \mathrm{w} / \mathrm{v}$ non-fat dry milk in TBS-T. After rinsing and $3 \times 15$ min washes with TBS-T, membranes were incubated with the secondary antibody (anti-mouse IgG HRP-linked diluted $1: 20000$ ) for $1.5 \mathrm{~h}$ at room temperature and washed with TBS-T. Proteins were detected with an enhanced chemiluminescence kit (ECL-Plus; Amersham Pharmacia Biotech Ltd., UK) and exposure to Kodak X-OMAT AR film. Membranes were stripped by incubation at $50^{\circ} \mathrm{C}$ for $30 \mathrm{~min}$ in $100 \mathrm{mM}$ 2-mercaptoethanol, 2\% SDS, $62.5 \mathrm{mM}$ Tris-HCl pH 6.7, washed twice in TBS-T for 10 min each and re-probed with anti-actin monoclonal antibody (\#C-2, Santa Cruz Biotechnology) diluted 1:500 in TBS-T, to serve as a loading control.

Gene expression analysis by microarray hybridization. This was performed using the Oligo GEArray Reagent kit from Superarray (MD, USA) which includes reagents for probe labeling, purification, hybridization and detection. For this procedure, two types of cell cultures were used: i) cells that were growing exponentially in complete medium containing $10 \%$ serum and harvested at $\sim 80 \%$ confluence (designated 'unsynchronised'); and ii) cells that had been serum-starved for $24 \mathrm{~h}$ and then allowed to grow for a further $24 \mathrm{~h}$ after the re-introduction of $10 \%$ serum into the growth medium and also harvested at $\sim 80 \%$ confluence (designated 'synchronised'). RNA was extracted from cell pellets $\left(5 \times 10^{6}\right.$ cells) using the RNeasy total RNA isolation kit (Invitrogen, USA) according to the manufacturer's protocol. This method yielded RNA that gave better results in the subsequent labeling and hybridisation procedures. RNA integrity was very important for efficient labeling and was checked by electrophoresis on formaldehyde agarose gels. Using the True labeling AMP-2 kits from Superarray, $3 \mu \mathrm{g}$ RNA were converted into cDNA with the kit G1 Truelabeling primer. This was used to synthesise cRNA by addition of kit RNA amplification mix and biotin UTP (Roche, USA). The labeled product was purified with the Superarray cRNA purification kit. About 2-3 $\mu \mathrm{g}$ in $0.75 \mathrm{ml}$ $\mathrm{H}-01$ GEAhyb hybridization buffer was added to an Oligo GEArray Human Breast Cancer Biomarkers Microarray OHS-402 filter (see http://superarray.com/genetable.php? pcatn=OHS-402 for identification of grid) which had been pre-wet with $5 \mathrm{ml}$ water for $5 \mathrm{~min}$ and pre-incubated with $2 \mathrm{ml}$ hybridization buffer for $4 \mathrm{~h}$ at $60^{\circ} \mathrm{C}$, for a further $18 \mathrm{~h}$ at $60^{\circ} \mathrm{C}$. The filter was then incubated in wash-buffer 1 (2X SSC and $1 \% \mathrm{SDS}$ ) for $15 \mathrm{~min}$ at $60^{\circ} \mathrm{C}$ and then in wash-buffer 2 (0.1X SSC, $0.5 \% \mathrm{SDS}$ ) for another $15 \mathrm{~min}$ at $60^{\circ} \mathrm{C}$. The filter was then blocked with kit GEA Q solution for $40 \mathrm{~min}$ and then incubated for $10 \mathrm{~min}$ with alkaline-phosphatase conjugated streptavidin. Following four 5-min incubations with $4 \mathrm{ml}$ of wash-buffer and two rinses with kit buffer $\mathrm{G}$, the filter was incubated for $5 \mathrm{~min}$ with $1 \mathrm{ml}$ of CDP Star chemiluminescent substrate. The filter was then blotted, enclosed in saran wrap and exposed to hyperfilm (Amersham Biotech, USA) for periods between $15 \mathrm{sec}$ to $10 \mathrm{~min}$. The developed hyperfilm was then scanned using an HP desktop scanner on grayscale set at $400 \mathrm{dpi}$ and the images transferred to a computer software package from Superarray to quantify the positive signals. The software was programmed to normalize the densitometric data, with background compensation, each spot being computed relative to 3 spots containing GAPDH. Derived values were then expressed as a ratio between MCF7 and pII cells. The hybridization experiments were repeated and an average value was recorded.

\section{Results}

Transfection efficiency was found to be very low with all three ER plasmids, and very few cells survived the initial selection in G418 following transfection. The procedure was repeated twice before any stable transfectants were obtained. It was a frequent observation that the majority of the cells died within about 7-10 days; those that remained ceased dividing and took much longer to die out. Occasionally surviving single cells would undergo a few divisions and then die. Several weeks post-selection a few cell clusters began to form small slow growing colonies. Most of these died out on attempting to expand them into fresh plates. After several attempts scattered cells were rescued from each transfection and over a period of several weeks colonies were noted for all the three plasmids. We made no quantitative assessment, but noted no obvious difference in terms of the numbers of colonies and the exposure time to the plasmid, the particular plasmid, whether or not 


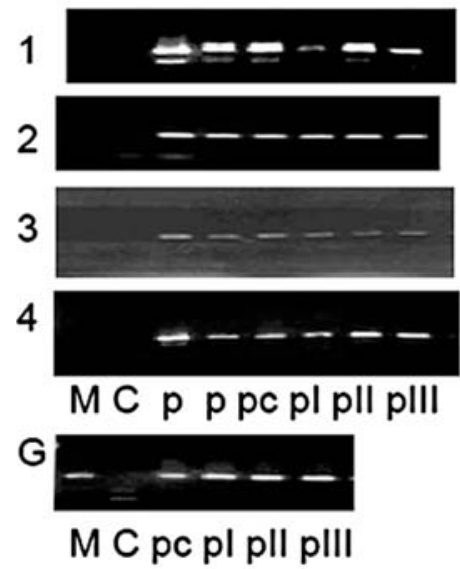

Figure 2. DNA was isolated from parental MCF7 cells (M) or from cells transfected with $p I$, $p I I$ or $p I I I$ siRNA constructs, or with control plasmid $(p c)$ and sequences were amplified using plasmid vector primers 1-4 as described in Materials and methods. PCR products were electrophoresed on $1 \%$ agarose gels. The bottom panel $\mathrm{G}$ shows products obtained from amplification with GAPDH primers. $\mathrm{C}$ is water blank and $\mathrm{p}$ is pII plasmid DNA.

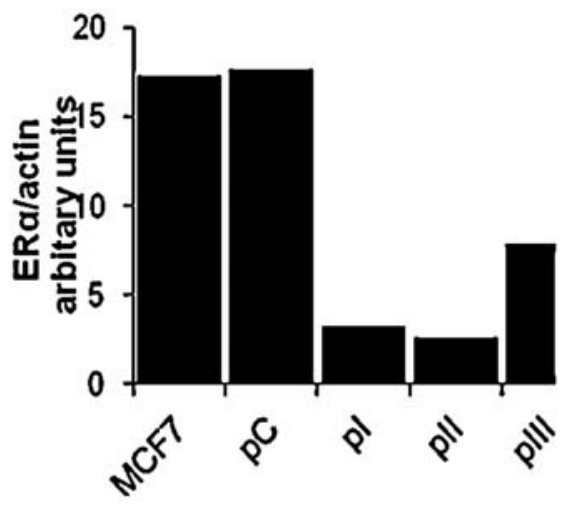

Figure 3. Real-time PCR analysis of ER $\alpha$ expression in parental MCF7 cells and in $\mathrm{pC}, \mathrm{pI}, \mathrm{pII}$ and $\mathrm{pIII}$ cells after 15 passages following transfection with the respective control or ER siRNA constructs. Total cellular RNA was reverse transcribed and amplified with the appropriate primers in the Roche LightCycler instrument as described in Materials and methods using syber green for quantitation. Histogram shows relative amounts of ER $\alpha$ to the amount of actin (mean of two determinations) calculated from the data generated by the LightCycler software package.

it was linearised or between the amounts that were used. However there appeared to be more survivors from transfections using the X-tremeGENE reagent. For each of the plasmids one growing colony was selected and expanded to mass culture. In the case of the control plasmid, we noted a much higher number of survivors which grew out of the selection media; also clones were established much faster.

Clones that survived at least 15 passages in G418 media were considered as stable. We analysed one cell line originating from each of the four plasmid transfections (designated pI, pII, pIII and pC). The presence of the plasmid in the cells (already inferred by the G418 resistance) was confirmed by PCR amplification of different regions of the plasmid which included sequences for the $\mathrm{amp}^{\mathrm{r}}$ gene, the T7 and U6 promoters and the neomycin ${ }^{r}$ gene. In each case the expected

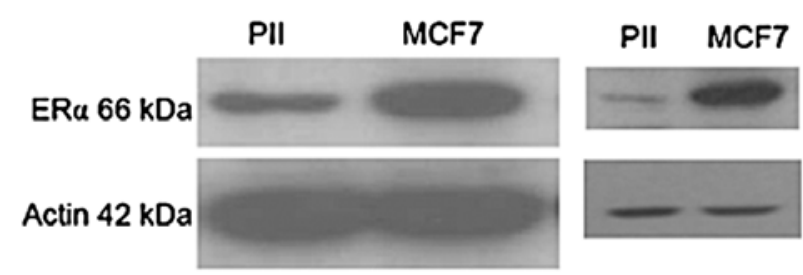

Figure 4. Protein extracts $(20 \mu \mathrm{g})$ from cell lines as indicated were electrophoresed on $7.5 \%$ polyacrylamide gels, blotted onto PVDF membranes and incubated sequentially with antisera to ER $\alpha$ or actin. Visualisation was achieved using the Amersham ECL detection system and exposure to Kodak X-OMAT AR film. Sizes of bands were verified by reference to rainbow M.wt standards (not shown). The two panels show separate experiments with different exposure times.

size products were observed, whereas these were absent from parental MCF7 cell DNA; all yielded GAPDH PCR products (Fig. 2). For the pII cells we also confirmed the presence of the plasmid ER siRNA sequence in the cellular DNA by amplification with a forward primer containing the appropriate ER sequence and a reverse primer located in the plasmid (data not shown).

The real-time PCR results illustrated in Fig. 3 show that cells containing the ER siRNA sequences, assayed after 15 passages, all showed reduced levels of ER mRNA compared to the parental MCF7 or the cells transfected with the control plasmid (pC). The knockdown effect was greatest in the pII cells and therefore this line was selected for further study. Fig. 4 shows a Western blotting indicating a marked reduction in the amount of ER protein in the pII cells compared with the parental MCF7 or the $\mathrm{pC}$ transfected cells, expressed relative to actin. The $\mathrm{pII}$ cells were re-examined after having undergone more than 30 passages. The data in Fig. 5 shows the results of real-time PCR amplification of both ER $\alpha$ and ERß1. The reduction in ER $\alpha$ was maintained. The pII cells also exhibited expression of ERß1 which was not detectable in the parent MCF7 cells. We observed a similar pattern of expression for ERß2, ie expressed in pII but not in the MCF7 cells (data not shown). We also examined the expression of three classical estrogen responsive genes, $\mathrm{pS} 2$, progesterone receptor (PR) and Cathepsin D. All of these were detected by PCR amplification in MCF7 cells. In comparison, pII cells had only a third as much of Cathepsin D and $<10 \%$ as much of $\mathrm{pS} 2$ and PR. The expression of two other genes, EGFR and erbB2 were also assessed by real-time PCR amplification. In both cases we observed a substantial reduction of $66 \%$ (EGFR) and $72 \%$ (erbB2) in pII as compared with MCF7 cells (Fig. 6).

The response of parental MCF7 and pII cells was assessed by cell growth assays. The data are illustrated in Fig. 7. The parental MCF7 cells were growth stimulated when exposed to $1 \mathrm{nM}$ estradiol over 4 days. Tamoxifen at $1 \mu \mathrm{M}$ inhibited the growth. Neither estradiol at 1 or $10 \mathrm{nM}$ nor tamoxifen had any significant effect on the growth of pII cells; higher concentrations of estradiol (50 and $100 \mathrm{nM}$; data not shown) were equally without effect.

In order to examine the global changes in gene expression resulting from the introduction of the ERsiRNA into the MCF7 cells, RNA from the parental and pII cell lines was converted 


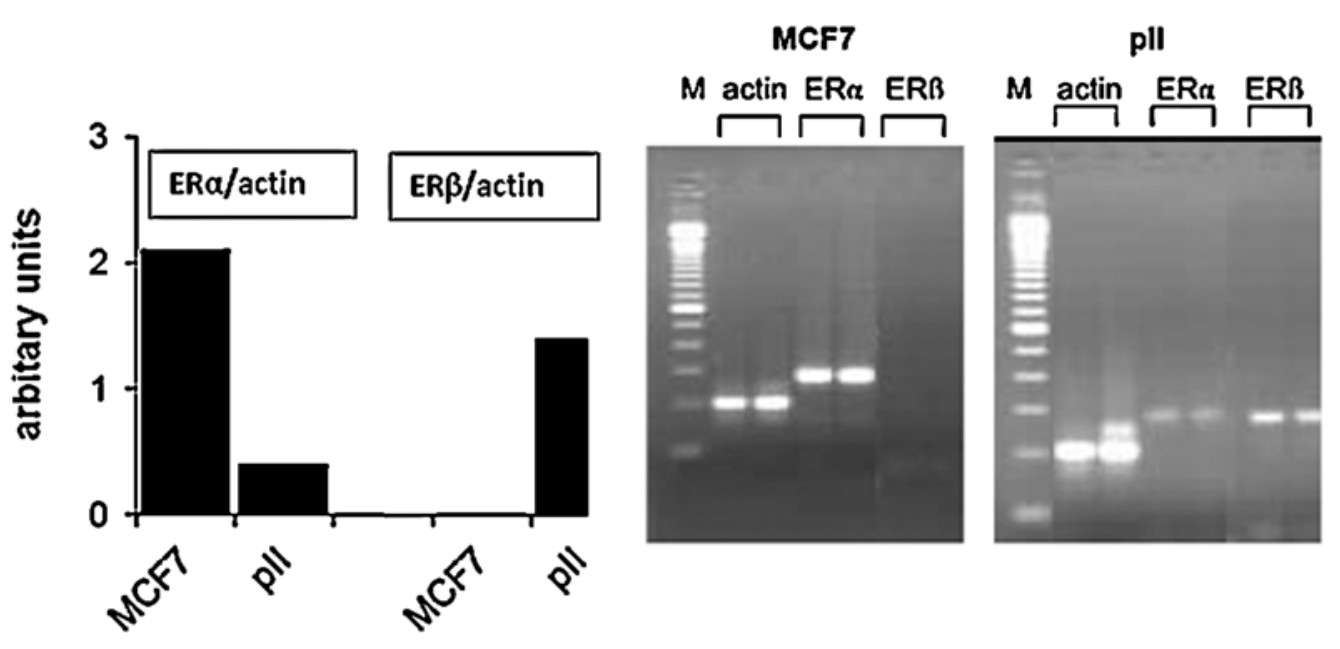

Figure 5. Real-time PCR analysis of ER expression in pII cells after $>30$ passages following transfection with pII ER siRNA construct compared with parental MCF7 cells. Total cellular RNA was reverse transcribed and amplified in the Applied Biosystems instrument as described in Materials and methods using SYBR Green for quantitation. Histogram shows relative amounts of ER $\alpha$ and ERß1 as a ratio to the amount of actin (mean of two determinations). After completion of 45 cycles, PCR products were also electrophoresed on $1 \%$ agarose gels; expected bands corresponding to actin, ER $\alpha$ and ERß1 were observed as indicated in the right panels for the MCF7 and pII cells (samples were analysed in duplicate). Lane M has $1 \mathrm{~kb}$ ladder molecular weight markers.

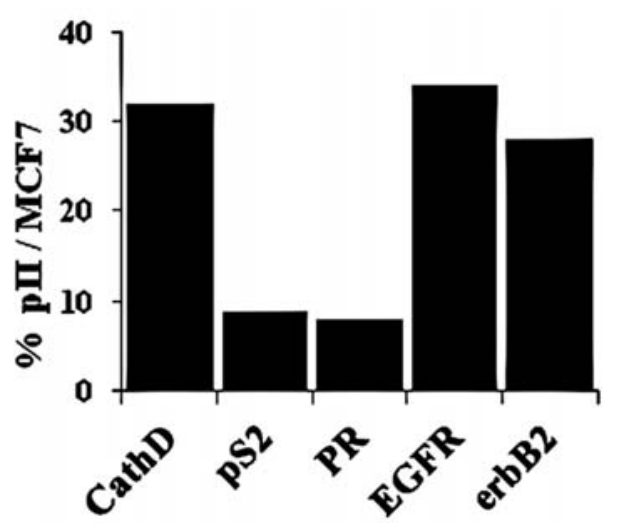

Figure 6. Comparative expression of indicated genes in pII and parental MCF7 cells. Total cellular RNA was reverse transcribed and amplified with the appropriate primers in the Roche LightCycler instrument as described in Materials and methods using syber green for quantitation. Histobars (mean of two determinations) show relative amounts of each gene normalized to actin present in pII cells as a percentage of the amount in MCF7 cells.

into labeled cDNA and hybridised to filter microarrays of oligo sequences corresponding to genes that have been reported in the published literature to have some association with breast cancer. Fig. 8 shows the filter arrays from one such hybridization. The spots were clearly visible and a number of differences could be easily discerned by eye. To test the reproducibility of this procedure and the consistency of expression, the hybridization was performed on duplicate filters using cRNA synthesized from RNA extracted from two different passages of the pII cells grown to similar density. An almost identical pattern was observed (data not shown).

The filters contain 288 spots including several 'housekeeping genes' and hybridization controls. Spot intensities were determined quantitatively using a software programme from Superarray and the results of two experiments was averaged. The programme displays both the raw densitometric

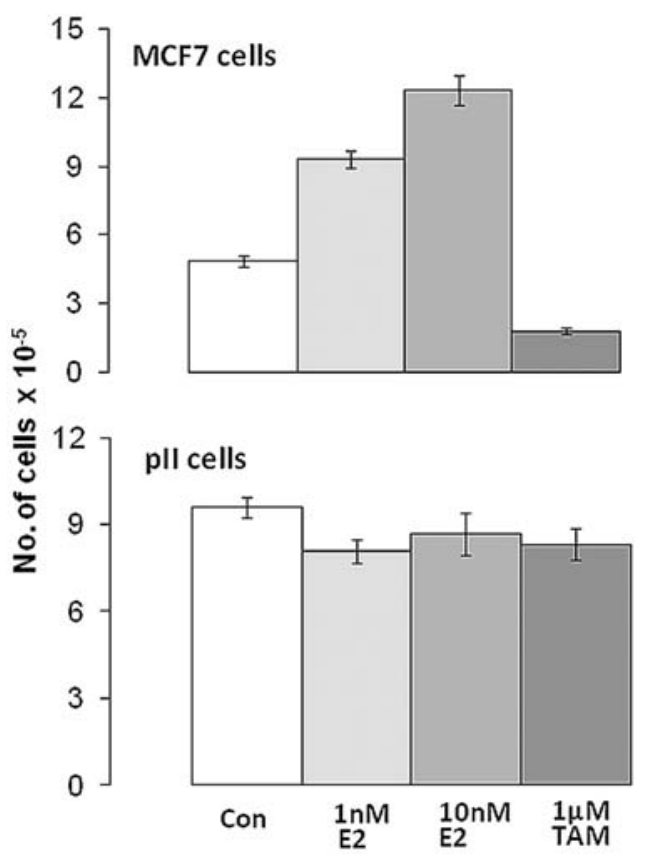

Figure 7. pII or MCF7 cells that had been maintained in MEM without phenol-red and $10 \%$ dextran-charcoal treated serum for 10 days were seeded into 12-well plates at a density of $2 \times 10^{4}$. After $24 \mathrm{~h}$, additions of estradiol (E2) or tamoxifen (TAM) at the indicated concentrations or vehicle alone (Con) were added and cells were counted after 4 days as described in Materials and methods. Histobars represent mean \pm SEM for 6 independent determinations.

data and a final derived value with background subtraction for each spot. An assignment of 0.01-0.05 relates to a spot which is just visible by eye. The results are displayed in Tables I-IV giving the derived densitometric values for positive spots and the ratio for pII to MCF7 parent cells. Only those genes are shown where there was either detection in only one cell line or a minimum 2 -fold difference in levels. Tables I 
PII

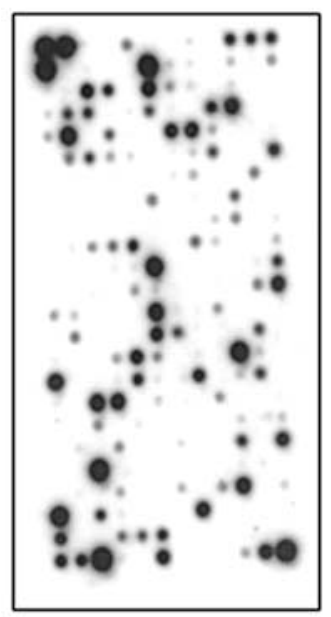

MCF7

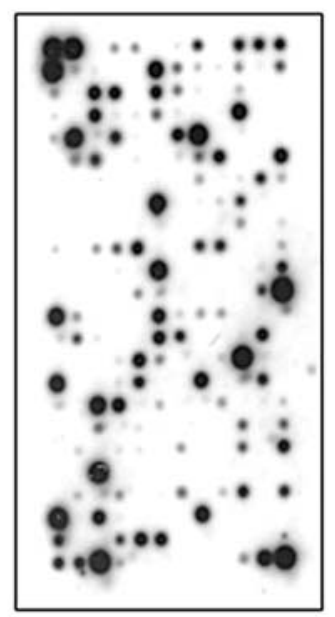

Figure 8. Biotin labeled cRNA was synthesized from total RNA extracted from either (serum synchronized) parental MCF7 or pII cells and hybridized to duplicate Oligo GEArray Human Breast Cancer Biomarkers Microarray OHS-402 arrays as described in Materials and methods. Visualisation was achieved with the ECL kit. Panels show scanned images (using an HP desktop scanner) of blots after 1-min exposure to Kodak X-OMAT AR film The software package from Superarray was used to quantitate signals with normalisation performed using the 3 GAPDH spots in the top right corner.

and II respectively list the genes which were found to be either down-regulated or elevated in the pII cells. Tables III and IV show corresponding data obtained with cell cultures that had been subjected to serum synchronisation. Almost half of the approximate 270 genes on the arrays showed no detectable signal. Seventy-four genes showed a 2-fold or more difference between unsynchronized MCF7 and pII cells (30 higher and 39 lower in pII cells). For the synchronized cells, 35 genes showed lower expression in pII cells and only 19 showed higher levels. Only three genes showed a significantly reversed ratio in expression between synchronised and unsynchronized cells; ATAD2 and TRIP13 due to elevated expression in synchronized MCF7 cells and AURKA due to elevation in synchronized pII cells. Nineteen out of 74 pII down-regulated genes were common to both synchronized and unsynchronized cells compared with $11 / 49$ pII up-regulated genes. These are highlighted in bold text in the tables. In both cases of increased but particularly decreased pII expression the genes showing the greatest change were mostly common between synchronized and unsynchronised cells; GRB7, PSMD7, KRT19, KRT18, AKT1, SYNCRIP, CYB5A and EVL for down-regulated in pII and QDPR, VIM, CD68, CA9, STMN1, CDK2, CTSC for up-regulated in pII cells.

\section{Discussion}

The purpose of this work was to establish, in long-term culture, a cell line that could be used to study the phenotypic behaviour of cells, previously estrogen-regulated, that had been induced to adopt an estrogen-independent state. We utilized a vectorbased siRNA strategy $(40,41)$ that involved translational blockade of ER mRNA to reduce the level of ER protein available to mediate transcriptional response to estrogen. MCF7 breast cancer cells were transfected with an expression
Table I. The genes showing down-regulation in pII cells,

\begin{tabular}{|c|c|c|c|c|}
\hline Gene ID & Name & $\mathrm{MCF}^{\mathrm{a}}$ & $\mathrm{pII}^{\mathrm{a}}$ & $\mathrm{MCF} 7 / \mathrm{pII}$ \\
\hline NM_005310 & GRB7 & 0.94 & 0.01 & 94 \\
\hline NM_002811 & PSMD7 & 0.55 & 0.01 & 55 \\
\hline NM_002276 & KRT19 & 2.00 & 0.04 & 50 \\
\hline NM_005163 & AKT1 & 0.49 & 0.01 & 49 \\
\hline NM_014417 & BBC3 & 0.98 & 0.05 & 20 \\
\hline NM_004448 & ERBB2 & 1.20 & 0.07 & 16 \\
\hline NM_006372 & SYNCRIP & 0.94 & 0.07 & 14 \\
\hline NM_000224 & KRT18 & 6.00 & 0.52 & 11 \\
\hline NM_016337 & EVL & 1.10 & 0.12 & 9 \\
\hline NM_001914 & CYB5A & 0.40 & 0.04 & 9 \\
\hline NM_000546 & TP53 & 0.08 & 0.01 & 8 \\
\hline NM_015984 & UCHL5 & 0.08 & 0.01 & 8 \\
\hline NM_021622 & PLEKHA1 & 0.51 & 0.07 & 7 \\
\hline NM_002613 & PDPK1 & 2.00 & 0.31 & 6 \\
\hline NM_000051 & ATM & 0.05 & 0.01 & 5 \\
\hline NM_004281 & BAG3 & 0.05 & 0.01 & 5 \\
\hline NM_000075 & CDK4 & 4.00 & 0.99 & 4 \\
\hline NM_024735 & FBXO31 & 0.68 & 0.18 & 4 \\
\hline NM_001908 & CTSB & 1.90 & 0.52 & 4 \\
\hline NM_004358 & CDC25B & 3.00 & 0.86 & 3 \\
\hline NM_003234 & TFRC & 2.00 & 0.65 & 3 \\
\hline NM_004324 & BAX & 0.12 & 0.05 & 2 \\
\hline NM_001916 & CYC1 & 0.89 & 0.38 & 2 \\
\hline NM_000757 & CSF1 & 0.23 & 0.10 & 2 \\
\hline NM_000759 & CSF3 & 0.23 & 0.10 & 2 \\
\hline NM_001909 & CTSD & 0.10 & 0.05 & 2 \\
\hline NM_000269 & NME1 & 5.00 & 2.50 & 2 \\
\hline NM_014422 & PIB5PA & 0.23 & & \\
\hline NM_003862 & FGF18 & 0.20 & & \\
\hline NM_003488 & AKAP1 & 0.19 & & \\
\hline NM_004827 & ABCG2 & 0.11 & & \\
\hline NM_004323 & BAG1 & 0.07 & & \\
\hline NM_021077 & NMB & 0.02 & & \\
\hline NM_000044 & AR & 0.01 & & \\
\hline NM_012154 & EIF2C2 & 0.01 & & \\
\hline NM_001982 & ERBB3 & 0.01 & & \\
\hline NM_000507 & FBP1 & 0.01 & & \\
\hline NM_006115 & PRAME & 0.01 & & \\
\hline NM_003600 & AURKA & 0.01 & & \\
\hline
\end{tabular}

a Densitometric values assigned to indicated gene normalized in each case to the GAPDH signal on the microarray OHS-402 from Superarray (http://superarray.com/genetable.php?pcatn=OHS-402). Blanks indicate that no signal was detectable. Final column represents the relative amounts between the two cell lines. Genes in bold text also down-regulated in non-synchronised cells.

vector that transcribes from a mammalian $\mathrm{H} 1$ promotor, a cloned ER sequence as an shRNA that is then spliced into 
Table II. The genes showing up-regulation in pII cells.

\begin{tabular}{|c|c|c|c|c|}
\hline Gene ID & Name & $\mathrm{MCF}^{\mathrm{a}}$ & $\mathrm{pII}^{\mathrm{a}}$ & $\mathrm{pII} / \mathrm{MCF} 7$ \\
\hline NM_004237 & TRIP13 & 0.01 & 0.57 & 57 \\
\hline NM_001168 & BIRC5 & 0.03 & 0.90 & 30 \\
\hline NM_016359 & NUSAP1 & 0.20 & 3.00 & 15 \\
\hline NM_005563 & STMN1 & 0.08 & 0.97 & 12 \\
\hline NM_001216 & CA9 & 0.03 & 0.24 & 8 \\
\hline NM_003380 & VIM & 0.10 & 0.84 & 8 \\
\hline NM_000320 & QDPR & 0.02 & 0.15 & 7 \\
\hline NM_002466 & MYBL2 & 0.16 & 0.80 & 5 \\
\hline NM_003878 & GGH & 0.13 & 0.67 & 5 \\
\hline NM_031966 & CCNB1 & 0.15 & 0.57 & 4 \\
\hline NM_018455 & CENPN & 0.20 & 0.80 & 4 \\
\hline NM_013296 & GPSM2 & 0.07 & 0.30 & 4 \\
\hline NM_001809 & CENPA & 0.09 & 0.40 & 4 \\
\hline NM_005252 & FOS & 0.02 & 0.05 & 3 \\
\hline NM_000017 & ACADS & 0.03 & 0.05 & 2 \\
\hline NM_002358 & MAD2L1 & 0.02 & 0.04 & 2 \\
\hline NM_001905 & CTPS & 0.11 & 0.28 & 2 \\
\hline NM_002417 & MKI67 & & 0.92 & \\
\hline NM_003258 & TK1 & & 0.92 & \\
\hline NM_024629 & MLF1IP & & 0.70 & \\
\hline NM_001251 & CD68 & & 0.52 & \\
\hline NM_014791 & MELK & & 0.48 & \\
\hline NM_001814 & CTSC & & 0.38 & \\
\hline NM_016448 & DTL & & 0.33 & \\
\hline NM_006101 & NDC80 & & 0.18 & \\
\hline NM_000598 & IGFBP3 & & 0.14 & \\
\hline NM_018136 & ASPM & & 0.13 & \\
\hline NM_014109 & ATAD2 & & 0.08 & \\
\hline NM_057735 & CCNE2 & & 0.06 & \\
\hline NM_006681 & NMU & & 0.05 & \\
\hline NM_007294 & BRCA1 & & 0.02 & \\
\hline NM_001282 & AP2B1 & & 0.01 & \\
\hline NM_004336 & BUB1 & & 0.01 & \\
\hline
\end{tabular}

aDensitometric values assigned to indicated gene normalized in each case to the GAPDH signal on the microarray OHS-402 from Superarray (http://superarray.com/genetable.php?pcatn=OHS-402). Blanks indicate that no signal was detectable. Final column represents the relative amounts between the two cell lines. Genes in bold text also up-regulated in synchronised cells.

21-23 nucleotide siRNA and targets to ER $\alpha$ mRNA. In common with others (42) our experience was that the selection of the most effective siRNA sequence is best determined empirically and that outcome is largely serendipitous (43); two of our three siRNA constructs achieved substantial reduction of cellular ER mRNA while the third was less
Table III. The genes showing down-regulation in serumsynchronised pII cells.

\begin{tabular}{|c|c|c|c|c|}
\hline Gene ID & Name & MCF7 $^{\mathrm{a}}$ & $\mathrm{pII}^{\mathrm{a}}$ & $\mathrm{MCF} 7 / \mathrm{pII}$ \\
\hline NM_002276 & KRT19 & 4.00 & 0.17 & 23 \\
\hline NM_006372 & SYNCRIP & 0.90 & 0.05 & 18 \\
\hline NM_002811 & PSMD7 & 0.53 & 0.03 & 18 \\
\hline NM_001914 & CYB5A & 0.69 & 0.05 & 14 \\
\hline NM_014109 & ATAD2 & 0.55 & 0.04 & 14 \\
\hline NM_005310 & GRB7 & 0.94 & 0.10 & 9 \\
\hline NM_005163 & AKT1 & 0.73 & 0.08 & 9 \\
\hline NM_006265 & RAD21 & 0.15 & 0.02 & 8 \\
\hline NM_016337 & EVL & 3.50 & 0.50 & 7 \\
\hline NM_002358 & MAD2L1 & 0.06 & 0.01 & 6 \\
\hline NM_000224 & KRT18 & 8.00 & 1.41 & 6 \\
\hline NM_004237 & TRIP13 & 2.20 & 0.71 & 3 \\
\hline NM_006281 & STK3 & 0.30 & 0.10 & 3 \\
\hline NM_001916 & CYC1 & 1.50 & 0.53 & 3 \\
\hline NM_003981 & PRC1 & 0.03 & 0.01 & 3 \\
\hline NM_014078 & MRPL13 & 2.00 & 0.81 & 2 \\
\hline NM_014417 & BBC3 & 0.58 & 0.26 & 2 \\
\hline NM_015984 & UCHL5 & 0.02 & 0.01 & 2 \\
\hline NM_178157 & FUT8 & 0.02 & 0.01 & 2 \\
\hline NM_174941 & CD163L1 & 0.02 & 0.01 & 2 \\
\hline NM_005496 & SMC4 & 0.06 & 0.03 & 2 \\
\hline NM_003234 & TFRC & 2.00 & 1.00 & 2 \\
\hline NM_004827 & ABCG2 & 0.16 & & \\
\hline NM_020166 & $\mathrm{MCCC} 1$ & 0.13 & & \\
\hline NM_001982 & ERBB3 & 0.07 & & \\
\hline NM_004323 & BAG1 & 0.05 & & \\
\hline NM_000633 & BCL2 & 0.05 & & \\
\hline NM_001333 & CTSL2 & 0.05 & & \\
\hline NM_000507 & FBP1 & 0.02 & & \\
\hline NM_003488 & AKAP1 & 0.01 & & \\
\hline NM_012154 & EIF2C2 & 0.01 & & \\
\hline NM_021077 & NMB & 0.01 & & \\
\hline NM_000926 & PGR & 0.01 & & \\
\hline NM_004163 & RAB27B & 0.01 & & \\
\hline
\end{tabular}

aDensitometric values assigned to indicated gene normalized in each case to the GAPDH signal on the microarray OHS-402 from Superarray (http://superarray.com/genetable.php?pcatn=OHS-402). Blanks indicate that no signal was detectable. Final column represents the relative amounts between the two cell lines. Genes in bold text also down-regulated in non-synchronised cells.

effective. Successfully transfected cells indicated by shortterm growth in antibiotic selective media mostly did not survive, in contrast to cells transfected with control plasmid lacking the siRNA sequence; the inference from this being that ER reduction was detrimental to survival of the MCF7 cells. In order to survive, transfectants would have to adapt to 
Table IV. The genes showing up-regulation in serumsynchronised pII cells.

\begin{tabular}{llccc}
\hline Gene ID & \multicolumn{1}{c}{ Name } & MCF7 & pII & MCF7/pII \\
\hline NM_000320 & QDPR & $\mathbf{0 . 0 2}$ & $\mathbf{0 . 3 5}$ & $\mathbf{1 8}$ \\
NM_003600 & AURKA & 0.10 & 0.37 & 4 \\
NM_002462 & MX1 & 0.01 & 0.04 & 4 \\
NM_005563 & STMN1 & $\mathbf{1 . 0 1}$ & $\mathbf{3 . 0 0}$ & $\mathbf{3}$ \\
NM_000017 & ACADS & $\mathbf{0 . 1 7}$ & $\mathbf{0 . 4 7}$ & $\mathbf{3}$ \\
NM_183356 & ASNS & 2.00 & 4.00 & 2 \\
NM_000059 & BRCA2 & 0.01 & 0.02 & 2 \\
NM_003380 & VIM & & $\mathbf{2 . 0 0}$ & \\
NM_001251 & CD68 & & $\mathbf{1 . 2 4}$ & \\
NM_001216 & CA9 & & $\mathbf{0 . 9 9}$ & \\
NM_001846 & COL4A2 & & 0.20 & \\
NM_006681 & NMU & & $\mathbf{0 . 1 9}$ & \\
NM_001814 & CTSC & & $\mathbf{0 . 1 5}$ & \\
NM_000598 & IGFBP3 & & $\mathbf{0 . 0 1}$ & \\
NM_000602 & SERPINE1 & & 0.01 & \\
NM_024774 & QSER1 & & 0.01 & \\
NM_007203 & PALM2-AKAP2 & & 0.01 & \\
\hline
\end{tabular}

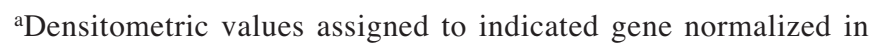
each case to the GAPDH signal on the microarray OHS-402 from Superarray (http://superarray.com/genetable.php?pcatn=OHS-402). Blanks indicate that no signal was detectable. Final column represents the relative amounts between the two cell lines. Genes in bold text also up-regulated in non-synchronised cells.

ER down-regulation which would account for the rarity and slowness of the occurrence.

Analysis of the selected pII cells showed that the reduction in ER mRNA compared with either untransfected parental cells or with cells transfected with the control plasmid, was maintained over many passages, implying stable integration and expression of the transfected plasmid whose presence was confirmed by PCR amplification of constituent sequences from extracted cellular DNA. Western blotting indicated that ER protein was also reduced in the pII cells.

In line with expectations, the growth rate of pII cells, in contrast with the parental cells, was not affected by the presence of estradiol and nor was it inhibited by the antiestrogen tamoxifen. This suggests that the pII cells are no longer dependent on estrogen and that disruption of the ER pathway does not prevent growth of these cells. This induction of estrogen insensitivity makes this model different from those which have been developed using long-term estrogen deprivation $(14,44)$. Cell lines derived under those conditions showed hypersensitivity to estrogen. This was explained in terms of a 4-10-fold increase in ER $\alpha$ including plasma membrane associated receptors (14) or by an enhanced transcriptional activity of $\mathrm{ER} \alpha$ (45). In both cases there is reported to be an associated compensatory increase in the ras/raf mediated MEK/MAPK signaling pathway activated through IGF1R or erbB2. Increased activation of the P13K/ AKT pathway has also been observed in both the LTED cells (46) as well as in the MCF7X line which however did not show the IGF1R or EGFR activation (15).

As the pII cells were established over a lengthy period of time, it is not possible to determine the absolute specificity of the ERsiRNA-induced lesion, but in view of the induction rather than suppression of ERB, it may be a reasonable assumption as Elbashir and colleagues among others have observed, that sequence specificity of siRNA is very stringent, as single base pair mismatches between the siRNA and its target mRNA can dramatically reduce silencing (38). Data regarding the role of ERß, are somewhat contradictory. Some studies (47) indicate that lower levels of ERß are associated with tamoxifen resistance while others report that ERß positivity is a poor prognostic factor and up regulated 2-fold in cells resistant to tamoxifen (48). In a recent study on breast tumours, it was reported that ERß2 expression significantly correlates with an ER $\alpha$ negative phenotype in breast cancers and causes reduction in recruitment of ER $\alpha$ to the $\mathrm{pS} 2$ promoter (49). pII cells exhibit expression of both ERß1 as well as ERß2 in which 26 unique amino-acid residues, termed exon 9 , replace the amino acids of exon 8 . The two isoforms may differentially modulate estrogen action. The ERß2 does not bind ligand, it fails to activate transcription of an estrogen sensitive reporter gene and it shows preferential heterodimerisation with ER $\alpha$ rather than with ER, thereby inhibiting $\mathrm{ER} \alpha \mathrm{DNA}$ binding resulting in a dominant-negative effect on ligand-dependent ER $\alpha$ reporter gene activity (50). This is consistent with the associated decrease of $\mathrm{pS} 2, \mathrm{PR}$ and Cathepsin D in the pII cells.

Activation of other growth factor driven signalling pathways is frequently cited as a likely mechanism of endocrine resistance (17) and EGFR/erbB2 signaling appears to be involved in acquired tamoxifen resistance in breast cancer cells (15) whose growth is also significantly inhibited by anti-EGFR reagents (37). Over-expression of erbB2 or of heregulin is reported to result in estrogen-independent growth and resistance to anti-estrogens $(51,52)$. In pII cells however, there is loss of EGFR, erbB2 and also erbB3 expression which is also accompanied by significant loss of GRB7 normally associated with erbB2. These observations were unexpected given the general reports of EGFR and erbB2 over-expression in aggressive ER- tumours, but this has also been observed in previously described anti-estrogen resistance models (53).

Lykkesfeldt and colleagues (54) have measured the expression of several genes in two panels of derivative MCF7 cell lines that were established by long-term exposure to various anti-estrogens. All had reduced ER $\alpha$ mRNA compared with the parental line. ERß was either unchanged or elevated in two lines, which underlines the over-simplistic view that the $\beta$ form is just a negative modulator of the $\alpha$ form. In the absence of ER $\alpha$ it may well have a different impact on the cell in a homo-dimeric form. Except in one case all the lines had decreased PR. For EGFR there was an increase in most but also a decrease in one and no change in another; erbB2 was generally unchanged. Although fulvestrant resistant cells showed increased activation of erbB3 this was 
not due to any rise in mRNA level; in pII cells we observed a fall in erbB3.

Low density microarray analysis was performed to determine the pattern of expression of a limited number of genes reported to have some association with breast cancer. As two different cell lines were being compared it was important to minimise differences that could simply reflect variations in growth conditions and or cell density. We also decided to compare the pII cells with the parental line rather than the pC line. A preliminary screen showed broad similarity between the parental MCF7 and pC cells. We examined both unsynchronised cells grown to approximately the same cell density and cells that had been serum-starved for $24 \mathrm{~h}$ and then allowed to recover in serum containing medium for $24 \mathrm{~h}$. Admittedly this is a controversial method for synchronising cells and may be noted in interpretation of the data. In this scenario however, it is more relevant that the process serves to reduce cell cycle differences even if synchronisation is not strictly achieved. It may also be noteworthy that the pattern of hybridisation observed for unsynchronised MCF7 cells in our hands, though not identical, was similar to that obtained from the array manufacturer SuperArray with a completely different sub-line of MCF7 (Barnett, unpublished data), suggesting that these lines are more phenotypically stable than generally assumed. The results of the microarray show, as may be expected, that both expression of genes and the differences between MCF7 and pII were to a large extent dependent upon the state of the cells. Differences in expression were less frequent in the synchronised cells and the magnitude of those differences was also much smaller. Among the genes that showed the most marked changes and which were common to synchronised and unsynchronised cells, some interesting observations can be made. In particular there is evidence in the pII cells (characterised by a more elongated appearance than the parental cells) of transition to a more mesenchymal phenotype with loss of keratin (KRT) 18/19 and marked increase in vimentin (VIM) (55). This has been seen in cell lines characterised by absence of ER and those that show more aggressiveness $(56,57)$ and with cancer cell migration in tumours (57) associated with changes in E cadherin and $B$ catenin. Similar expression patterns have also been reported in drug-resistant cell lines (59). It has been suggested that progression of breast cancer may be due in part to tumour cells losing their epithelial features and gaining mesenchymal properties; a keratin-rich network connecting to adherens junctions and hemidesmosomes, to a vimentin-rich network connecting to focal adhesions (55). It will be of interest to examine other molecules associated with vimentin.

Interestingly, stathmin (STMN1), a phosphoprotein that is proposed to act as a relay integrating diverse cell signaling pathways and a key regulator of cell division for its ability to destabilize microtubules, is over-expressed in pII cells. Overexpression of STMN1 is also correlated with loss of steroid receptors in breast cancers (60).

Another striking feature of pII cells is the appearance of CD68, a macrophage specific marker. Together with high carbonic anhydrase IX (CA9) and lower Bcl2-associated athanogene (BAG1) these features were reported as indicative of high risk of distant metastases (61). On the other hand we observe a reduction in Enah/Vasp-like gene (EVL) which has been reported to be up-regulated in breast cancers in correlation with advanced clinical stage and which increased MCF7 cell motility (62).

The decrease in AKT1 also seems to correlate with the lower erbB2 in pII cells Akt1 in the mouse is a requirement for erbB2-induced mammary tumorigenesis (63) in contrast with the TAM-R line of Jordan et al (64) in which there is no change in the level but increased phosphorylation.

We could not detect EGFR on the microarrays but both erbB2 and erbB3 were lowered in pII cells as we found with the PCR assays. It may well be that as argued by Normanno and colleagues (17) cellular response is governed by the nature of the stimulus/insult and leads to variable phenotypes. In this case pII cells have assumed an endocrine independent status without an obvious involvement of an EGFR substituted dependence.

In conclusion, we have established a cell line that exhibits a permanent ER-depleted phenotype. These cells are not responsive to estrogen and are not growth inhibited by tamoxifen. They also exhibit a series of changes in the levels of gene transcripts encoding proteins many of which have been associated with ER- breast cancers, increased aggressiveness and motility. We have identified a number of genes that may be important in the transition of breast cells to an estrogen independent phenotype. These cells have some similarities with other MCF7 lines that have been manipulated to achieve models for studying endocrine resistance although established in quite different ways. Our pII cells may be useful as a model for situations in which tumours display loss of ER protein rather than where there appears to be anti-estrogen insensitivity in the absence of ER loss. Comparisons in terms of overall patterns of gene expression are however limited by the lack of descriptive data on the same sets of genes in the various publications. In this respect, analysis is intended using high density affymetrix gene chips to look at a much wider spectrum of genes. The differences identified in our array screens will also need to be validated with PCR measurements before promising candidates are studied for tissue expression.

A further issue for the present array analysis may be unintended 'off target' effects caused by mimicry by siRNA of natural microRNA target recognition (65). As this, if it occurs, is likely to be a sequence specific phenomenon, comparisons with cells transfected with other sequences which is the common practice, particularly after long-term selection, may also provide misleading results and we therefore elected not to do this. However, it is mentioned as a cautionary note. Studies are in progress with a view to examining the responsiveness of these cells to a variety of growth inducers to identify the mitogenic pathways that have substituted for the loss of ER regulation.

\section{Acknowledgements}

This work was supported by Grant no. PC02/04 from Kuwait University Research Administration. We are also grateful to Dr Fahad Al Mulla for use of some facilities in the HSC Research Core Facility which is also funded by Kuwait University Research Administration (Grants GM01/05 AND GM01/01). 


\section{References}

1. Jensen EV: The oestrogen receptor: a model for molecular medicine. Clin Cancer Res 9: 1980-1989, 2003.

2. Berry DA, Cronin KA, Plevritis SK, Fryback DG, Clarke L, Zelen M, Mandelblatt JS, Yakovlev AY, Habbema JD and Feuer EJ: Effect of screening and adjuvant therapy on mortality from breast cancer. N Engl J Med 353: 1784-1792, 2005.

3. Strasser-Weippl K and Goss E: Advances in adjuvant hormonal therapy for postmenopausal women. J Clin Oncol 23: 1751-1759, 2005 .

4. MacGregor JI and Jordan VC: Basic guide to the mechanisms of anti-estrogen action. Pharmacol Rev 50: 151-196, 1998.

5. Early Breast Cancer trialists Collaborative Group: Effects of chemotherapy and hormonal therapy for ealr breast cancer on reccurrence and 15-year survival: an overview of the randomized trials. Lancet 365: 1687-1717, 2005.

6. Cuzick J, Powles T, Veronesi U, Forbes J, Edwards R, Ashley S and Boyle P: Overview of the main outcomes in breast cancer prevention trials. Lancet 361: 296-300, 2003.

7. Tzukerman MT, Esty A, Santiso-Mere D, Danielian P, Parker MG, Stein RB, Pike JW and McDonnell DP: Human estrogen receptor transactivational capacity is determined by both cellular and promoter context an dmediated by two functionally distinct intramolecular regions. Mol Endocrinol 8: 21-30, 1994.

8. McDonnel DP, Clemm DL, Hermann T, Goldman ME and Pike JW: Analysis of estrogen receptor function in vitro reveals three distinct classes of anti-estrogens. Mol Endocrinol 9: 659-669, 1995.

9. Ariazi EA, Ariazi JL, Cordera F and Jordan VC: Estrogen receptors as therapeutic targets in breast cancer. Curr Top Med Chem 6: 181-202, 2006

10. Cranney A, tugwell P, Zytaruk N, Robinson V, Weaver B, Adachi J, Wells G, Shea B and Guyatt G: IV. Meta-analysis of Raloxifene for the prevention and treatment of postmenopausal osteoporosis. Endocr Rev 23: 524-528, 2002.

11. Sanchez R, Nguyen D, Rocha W, White JH and Mader S: Diversity in the mechanisms of gene regulation by estrogen receptors. Bioessays 24: 244-254, 2002.

12. Carlson RW: The history and mechanism of action of fulvestrant. Clin Breast Cancer 6 (Suppl. 1): S5-S8, 2005.

13. Jemal A, Murray T, Ward E, Samuels A, Tiwari RC, Ghafoor A Feuer EJ and Thun MJ: Cancer Statistics 2005. CA Cancer J Clin 55: 10-30, 2005.

14. Santen RJ, Song RX, Zhang Z, Kumar R, Jeng MH, Masamura S, Yue W and Berstein L: Adaptive hypersensitivity to estrogen: mechanism for superiority of aromatase inhibitors over selective estrogen receptor modulators for breast cancer treatment and prevention. Endocr Relat Cancer 10: 111-130, 2003.

15. Nicholson RI, Staka C, Boyns F, Hutcheson IR and Gee JM: Growth factor-driven mechanisms associated with resistance to estrogen deprivation in breast cancer; new opportunities for therapy. Endocr Relat Cancer 11: 623-641, 2004.

16. Ring A and Dowsett M: Mechanisms of tamoxifen resistance. Endocr Relat Cancer 11: 643-658, 2004.

17. Normanno N, Di Maio M, De Maio E, De Luc A, De Matteis A, Giordano A and Perrone F: On behalf of the NCI-Naples Breast Cancer Group. Mechanisms of endocrine resistance and novel therapeutic strategies in breast cancer. Endocr Relat Cancer 12: 721-747, 2005.

18. Lewis JS and Jordan VC: Selective estrogen receptor modulators (SERMs): mechanisms of anticarcinogenesis and drug resistance. Mutat Res 591: 247-263, 2005.

19. Song RX, Santen RJ, Kumar R, Adam L, Jeng MH, Masamura S and Yue W: Adaptive mechanisms induced by long-term estrogen deprivation in breast cancer cells. Mol Cell Endocrinol 193: 29-42, 2002.

20. Brünner N, Frandsen TL, Holst-Hansen C, Bei M, Thompson EW, Wakeling AE, Lippman ME and Clarke R: MCF7/LCC2: A 4hydroxytamoxifen resistant human breast cancer variant that retains sensitivity to the steroidal anti-estrogen ICI 182,780 . Cancer Res 53: 3229-3232, 1993.

21. McClelland RA, Barrow D, Madden TA, Dutkowski CM, Pamment J, Knowlden JM, Gee JMW and Nicholson RI: Enhanced epidermal growth factor receptor signaling in MCF7 breast cancer cells after long-term culture in the presence of the pure anti-estrogen ICI 182,780 (Faslodex). Endocrinology 142: 2776-2788, 2001.
22. Fan P, Wang J, Santen RJ and Yue W: Long-term treatment with tamoxifen facilitates translocation of estrogen receptor (alpha) out of the nucleus and enhances its interaction with EGFR in MCF-7 breast cancer cells. Cancer Res 67: 1352-1360, 2007.

23. Gutierrez MC, Detre S, Johnston S, Mohsin SK, Shou J, Allred DC, Schiff R, Osborne CK and Dowsett M: Molecular changes in tamoxifen-resistant breast cancer: relationship between estrogen receptor, HER-2 and p38 mitogen activated protein kinase. J Clin Oncol 23: 2469-2476, 2005.

24. Sharma D, Saxena NK, Davidson NE and Vertino PM: Restoration of tamoxifen sensitivity in estrogen receptor-negative breast cancer cells: tamoxifen-bound reactivated ER recruits distinctive co-repressor complexes. Cancer Res 66: 6370-6378, 2006.

25. Garcia M, Derocq D, Freiss G and Rochefort H: Activation of estrogen receptor transfected into a receptor-negative breast cancer cell line decreases the metastatic and invasive potential of the cells. Proc Natl Acad Sci USA 89: 11538-11542, 1992.

26. Van den Berg HW, Lynch M, Martin J, Nelson J, Dickson GR and Crockard AD: Characterisation of a tamoxifen-resistant variant of the ZR-75-1 human breast cancer cell line (ZR-75-9a1) and ability of the resistant phenotype. Br J Cancer 59: 522-526, 1989.

27. Sommer A, Hoffmann J, Lichtner RB, Schneider MR and Parczyk K: Studies on the development of resistance to the pure ant estrogen Faslodex in three human breast cancer cell lines. J Steroid Biochem Mol Biol 85: 33-47, 2003.

28. Fan M, Yan PS, Hartman-Frey C, Chen L, Paik H, Oyer SL, Salisbury JD, Cheng AS, Li L, Abbosh PH, Huang TH and Nephew KP: Diverse gene expression and DNA methylation profiles correlate with differential adaptation of breast cancer cells to the anti-estrogens tamoxifen and fulvestrant. Cancer Res 66: 11954-11966, 2006.

29. Larsen SS, Madsen MW, Jensen BL and Lykkesfeldt AE: Resistance of human breast-cancer cells to the pure steroidal anti-estrogen ICI 182,780 is not associated with a general loss of estrogen-receptor expression or lack of estrogen responsiveness. Int J Cancer 72: 1129-1136, 1997.

30. Brünner N, Boysen B, Jirus S, Skaar TC, Holst-Hansen C, Lippman J, Frandsen T, Spang-Thomsen M, Fuqua SA and Clarke R: MCF7/LCC9: an ant estrogen-resistant MCF-7 variant in which acquired resistance to the steroidal ant estrogen ICI 182,780 confers an early cross-resistance to the non-steroidal ant estrogen tamoxifen. Cancer Res 57: 3486-3493, 1997.

31. Nemere I, Pietras RJ and Blackmore PF: Membrane receptors for steroid hormones: signal transduction and physiological significance. J Cell Biochem 88: 438-445, 2003.

32. Li L, Haynes MP and Bender JR: Plasma membrane localisation and function of the estrogen receptor alpha variant (ER46) in human endothelial cells. Proc Natl Acad Sci USA 100: 4807-4812, 2003.

33. Razandi M, Alton G, Pedram A, Ghonshani S, Webb P and Levin ER: Identification of a structural determinant necessary for the localization and function of estrogen receptor at the plasma membrane. Mol Cell Biol 23: 1633-1646, 2003.

34. Chung YL, Sheu ML, Yang SC, Lin CH and Yen SH: Resistance to tamoxifen induced apoptosis is associated with direct interaction between HER2/neu and cell membrane estrogen receptor in breast cancer. Int J Cancer 97: 306-312, 2002.

35. Kahler S, Nuedling S, van Eickels M, Vetter H, Meyer R and Grohe C: Estrogen receptor alpha rapidly activates the IGF-1 receptor pathway. J Biol Chem 275: 18447-18453, 2000.

36. De Laurentiis M, Arpino G, Massarelli E, Ruggiero A, Carlomagno C, Ciardiello F, Tortora G, D'Agostino D, Caputo F, Cancello G, Montagna E, Malorni L, Zinno L, Lauria R, Bianco AR and De Placido S: A meta-analysis on the interaction between HER-2 expression and response to endocrine treatment in advanced breast cancer. Clin Cancer Res 11: 4741-4748, 2005

37. Gee JM, Harper ME, Hutcheson IR, Madden TA, Barrow D, Knowlden JM, McClelland RA, Jordan N, Wakeling AE and Nicholson RI: The anti-epidermal growth factor receptor agent gefitinib (ZD1839/Iressa) improves anti-hormone response and prevents development of resistance in breast cancer in vitro. Endocrinology 144: 5105-5117, 2003.

38. Elbashir SM, Harborth J, Lendeck BW, Yalcin A, Weber K and Tuschl T: Duplexes of 21-nucleotide RNAs mediate RNA interference in cultured mammalian cells. Nature 411: 494-498, 2001. 
39. Pfaffl MW: A new mathematical model for relative quantitation in real-time RT-PCR. Nucleic Acids Res 29: E45-E50, 2001.

40. Brummelkamp TR, Bernards R and Agami R: A system for stable expression of short interfering RNAs in mammalian cells. Science 296: 550-553, 2002.

41. Sui G, Soohoo C, Affar B, Gay F, Shi Y, Forrester WC and Shi Y: A DNA vector-based RNAi technology to suppress gene expression in mammalian cells. Proc Natl Acad Sci USA 99: 5515-5520, 2002.

42. Fu HJ, Jia LT, Bao W, Zhao J, Meng YL, Wang CJ, Yao LB, Chen SY and Yang AG: Stable knockdown of estrogen receptor alpha by vector-based RNA interference suppresses proliferation and enhances apoptosis in breast cancer cells. Cancer Biol Ther 5: 842-847, 2006.

43. Leu YW, Yan PS, Fan M, Jin VX, Liu JC, Curran EM, Welshons WV, Wei SH, Davuluri RV, Plass C, Nephew KP and Huang THM: Loss of estrogen receptor signaling triggers epigenetic silencing of downstream targets in breast cancer. Cancer Res 64: 8184-8192, 2004.

44. Chan CM, Martin LA, Johnston SR, Ali S and Dowsett M: Molecular changes associated with the acquisition of oestrogen hypersensitivity in MCF-7 breast cancer cells on long-term oestrogen deprivation. J Steroid Biochem Mol Biol 81: 333-341, 2002.

45. Martin LA, Farmer I, Johnston SR, Ali S, Marshall C and Dowsett M: Enhanced estrogen receptor (ER) alpha, ERBB2, and MAPK signal transduction pathways operate during the adaptation of MCF-7 cells to long-term estrogen deprivation. J Biol Chem 278: 30458-30468, 2003.

46. Yue W, Wang JP, Conaway MR, Li Y and Santen RJ: Adaptive hypersensitivity following long-term estrogen deprivation: involvement of multiple signal pathways. J Steroid Biochem Mol Biol 86: 265-274, 2003.

47. Elledge RM, Green S, Pugh R, Allred DC, Clark GM, Hill J, Ravdin P, Martino S and Osborne CK: Estrogen receptor (ER) and progesterone receptor $(\mathrm{PgR})$, by ligand-binding assay compared with ER, PgR and pS2, by immunohistochemistry in predicting response to tamoxifen in metastatic breast cancer: a Southwest Oncology Group Study. Int J Cancer 89: 111-117, 2000.

48. Speirs V, Malone C, Walton DS, Kerin MJ and Atkin SL: Increased expression of estrogen receptor beta mRNA in tamoxifen-resistant breast cancer patients. Cancer Res 59: 5421-5424, 1999.

49. Zhao C, Matthews J, Tujague M, Wan J, Ström A, Toresson G, Lam EW, Cheng G, Gustafsson JA and Dahlman-Wright K: Estrogen receptor beta2 negatively regulates the transactivation of estrogen receptor alpha in human breast cancer cells. Cancer Res 67: 3955-3962, 2007

50. Ogawa S, Inoue S, Watanabe T, Orimo A, Hosoi T, Ouchi Y and Muramatsu M: Molecular cloning and characterization of human estrogen receptor-Cx: a potential inhibitor of estrogen action in human. Nucleic Acids Res 26: 3505-3512, 1998.

51. Tang CK, Perez C, Grunt T, Waibel C, Cho C and Lupu R: Involvement of heregulin-beta2 in the acquisition of the hormoneindependent phenotype of breast cancer cells. Cancer Res 56: 3350-3358, 1996.

52. Liu Y, el-Ashry D, Chen D, Ding IY and Kern FG: Emergence of MCF-7 cells over-expressing a transfected epidermal growth factor receptor (EGFR) under estrogen-depleted conditions: evidence for a role of EGFR in breast cancer growth and progression. Cell Growth Differ 5: 1263-1274, 1994.
53. Larsen SS, Egeblad M, Jäättelä M and Lykkesfeldt AE: Acquired anti-estrogen resistance in MCF-7 human breast cancer sublines is not accomplished by altered expression of receptors in the ErbB-family. Breast Cancer Res Treat 58: 41-56, 1999.

54. De Cremoux P, Tran-Perennou C, Brockdorff BL, Boudou E, Brünner N, Magdelénat H and Lykkesfeldt AE: Validation of real-time RT-PCR for analysis of human breast cancer cell lines resistant or sensitive to treatment with anti-estrogens. Endocr Relat Cancer 10: 409-418, 2003.

55. Kokkinos MI, Wafai R, Wong MK, Newgreen DF, Thompson EW and Waltham M: Vimentin and epithelial-mesenchymal transition in human breast cancer - observations in vitro and in vivo. Cells Tissues Organs 185: 191-203, 2007.

56. Thompson EW, Paik S, Brunner N, Sommers CL, Zugmaier G, Clarke R, Shima TB, Torri J, Donahue S, Lippman ME, et al: Association of increased basement membrane invasiveness with absence of estrogen receptor and expression of vimentin in human breast cancer cell lines. J Cell Physiol 150: 534-544, 1992.

57. Sommers CL, Walker-Jones D, Heckford SE, Worland P Valverius E, Clark R, McCormick F, Stampfer M, Abularach S and Gelmann EP: Vimentin rather than keratin expression in some hormone-independent breast cancer cell lines and in oncogene-transformed mammary epithelial cells. Cancer Res 49: 4258-4263, 1989

58. Gilles C, Newgreen D, Sato H and Thompson EW: Matrix metalloproteases and epithelial - to mesenchymal transition: implications for carcinoma metastasis. In: Rise and Fall of Epithelial Phenotype. Savagner P (ed). Landes Bioscience Publishers, Georgetown, pp297-315, 2004.

59. Sommers CL, Heckford SE, Skerker JM, Worland P, Torri JA, Thompson EW, Byers SW and Gelmann EP: Loss of epithelial markers and acquisition of vimentin expression in adriamycinand vinblastine-resistant human breast cancer cell lines. Cancer Res 52: 5190-5197, 1992.

60. Curmi PA, Noguès C, Lachkar S, Carelle N, Gonthier MP, Sobel A, Lidereau R and Bièche I: Overexpression of stathmin in breast carcinomas points out to highly proliferative tumours. Br J Cancer 82: 142-150, 2000.

61. Cobleigh MA, Tabesh B, Bitterman P, Baker J, Cronin M, Liu ML, Borchik R, Mosquera JM, Walker MG and Shak S: Tumor gene expression and prognosis in breast cancer patients with 10 or more positive lymph nodes. Clin Cancer Res 11: 8623-8631, 2005

62. Hu LD, Zou HF, Zhan SX and Cao KM: EVL (Ena/VASP-like) expression is up-regulated in human breast cancer and its relative expression level is correlated with clinical stages. Oncol Rep 19: 1015-1020, 2008

63. Ju X, Katiyar S, Wang C, Liu M, Jiao X, Li S, Zhou J, Turner J, Lisanti MP, Russell RG, Mueller SC, Ojeifo J, Chen WS, Hay N and Pestell RG: Akt1 governs breast cancer progression in vivo. Proc Natl Acad Sci USA 104: 7438-7443, 2007.

64. Jordan NJ, Gee JM, Barrow D, Wakeling AE and Nicholson RI: Increased constitutive activity of PKB/Akt in tamoxifen resistant breast cancer MCF-7 cells. Breast Cancer Res Treat 87: 167-180, 2004.

65. Jackson AL, Burchard J, Schelter J, Chau BN, Cleary M, Lim L and Linsley PS: Widespread siRNA 'off-target' transcript silencing mediated by seed region sequence complementarity. RNA 12: 1179-1187, 2006. 